\title{
Mediating Effect of Service Quality on the Relationship between Employees Empowerment, and Customer Satisfaction in Hotel Industry
}

\author{
${ }^{1}$ Bello Yekinni Ojo Ph.D., ${ }^{2}$ Bello Mercy Busayo, ${ }^{3}$ Ifegbu Lawrencia Ifeoma Ph. D \\ ${ }^{I}$ Faculty of Management Sciences Department of Hospitality Management and Tourism University of Port \\ Harcourt, Rivers State, Nigeria \\ ${ }^{2}$ School of Applied Sciences Department of Hospitality Management Auchi Polytechnic Auchi, Nigeria \\ ${ }^{3}$ Faculty of Management Sciences Department of Hospitality and Tourism Management Imo State University \\ Owerri, Imo State, Nigeria
}

\begin{abstract}
This study explore the mediating effect of service quality on the relationship between employee empowerment and customer satisfaction in hotel industry. To achieve this objective, questionnaire was used to collect data from 106 each of front office staff and customers of selected hotels in Benin City, Nigeria. Multiple regression analysis method was used for the analysis of the data collected. Result shows that service quality has indirect effect on the relationship between employee's empowerment and customer satisfaction in hotel industry in Benin City. This implies that employee's empowerment did not ordinarily translate to customer satisfaction in Hotel industry without offering of quality service. It was concluded that empowered front line staff triggers quality service delivery, and quality service offered to customers ensure their satisfaction. Furthermore, it was suggested that emphasis on the right service culture, and organisational structure that promote meaning, competence, self-determination, and impact should be encouraged among the front office staff in Hotel industry. This will ensure that quality service that could translate to customer satisfaction is delivered. Limitations in this study include that only the front office staff in hotel industry was focused, thus, did not consider other contact staff in other departments. Hotels in Benin City was investigated in the current study, the sample population could be extended to hotels in other local government areas and major towns in Edo State, hence, provides better information and results.
\end{abstract}

Keywords: Employee empowerment, Customer's satisfaction, Structural empowerment, and Psychological empowerment.

\section{Introduction}

The inability of the management to control the service encounter makes the employees responsible for the quality of service delivered to the customers (Ahmed \& Rafiq, 2003; Igbojekwe, 2002; Palmer, 2001). The quality of the service and the satisfaction the customer may derive will be an assessment of the entire service experience, including, the degree of empowerment of staff in an organisation (Bello \& Bello, 2015). Employees therefore become the voice and face of the organization, hence, require proportion of authority to make decisions regarding service delivery (Timothy \& Abubakar, 2013). This is one of the arguments of employee empowerment since the employees act as an interface between the customers and the organization. This practice directly enhances quality service delivery if well managed, and as well ensures customer satisfaction (Grönroos, 2001). However, it had been established that there is a positive correlation between employee's empowerment and customer's satisfaction (Timothy \& Abubakar, 2013; Ogutu \& Oloko, 2012; Odindo \& Delvin, 2010; Sparks, et al., 1997). Bello (2012) suggested that employee's empowerment did not ordinarily translate to customer satisfaction without offering of quality services. This implies that employee's empowerment that translates to quality service could lead to customer's satisfaction. The author argued that service quality could have a positive mediating effect on the relationship between employee's empowerment, and customer's satisfaction. It is therefore pertinent to state that limited study has examined the mediating effect of service quality on the relationship between employee's empowerment, and customer's satisfaction in respect of hotel front office staff (Isimoya \& Bakarey, 2013).

The present study focused on the front office staff of hotels in Benin City. The reason for the choice of the front office department of hotels is that the department it is the first point of call for an incoming guest and the last port of call for an outgoing guest (Ogutu \& Okolo, 2012; Bello \& Bello, 2010). Hence, a customer gets their first and possibly their last impression about the general services offered by the hotel in the front office. This could determine if the customer will make a return visit or not, hence, impact either positively, and or negatively on the hotel sales. The economic value of the hotel front office made the department to be very unique among other departments in the hotel industry, thus, the room sales made in the front office accounted 
for over $65 \%$ of the total hotel revenue (Bello \& Bello, 2010; Igbojekwe, 2009). This implies that the front office department is the sales nucleus of the hotel industry. In view of this, empowerment of front office staff could enhance their sense of personal power and allows them to delight their customers, thus, leading to more patronage, and revenue generation. Aside the above, functionally, the hotel front office is referred to as the "hub and the heart" of the hotel due to the various service encounter, and the whole of guest activities being managed in the unit (Bello \& Bello, 2015). It could also be referred to as the "eyes and ears", hence, through its flows of communication with every other department about the service needs of the customers, including, the service instructions that emanate from the unit for the service of the guests, the hotel front office is central to the general management of service encounter behaviour of the hotel (Odindo \& Delvin, 2010). This further confirmed the hotel front office as the service nucleus of the hotel; thus, its personnel play a critical role in service organizations of the hotel by explaining and providing answers to customers' inquiries on the spot rather than waiting for managers' feedback and judgment (Lee, Nam, Park \& Lee., 2006). In view of this, the present study aim to examine the mediating effect of service quality on the relationship between employee's empowerment, and customer's satisfaction in the context of employees of the front office in hotel industry in Benin City, Nigeria.

\section{Theoretical Orientation}

No single theory have been reported to explaining the mediating effect of service quality on the relationship between employees empowerment, and customer's satisfaction in respect of Hotel industry, hence, the researchers reviewed related theories on each of the three constructs as of the following.

\section{Empowerment Theory}

Sun et al. (2012) and Menon (2001) claimed that empowerment theory has three broad categories which include leadership, structural, and psychological empowerment. However, the theory has been introduced and explained more frequently using two dimensions- structural and psychological dimensions. Kanter's theory of empowerment explains the structural empowerment dimension while Spreitzer explains the Psychological empowerment (Kanter, 1993; Spreitzer, 1995).Kanter's structural theory of empowerment argued that the structure of opportunities, power, and the proportions of people from different groups explained their behaviour within an organisation (Kanter, 1993). As it applied to the hotel front office, the structure of opportunities of the hotel, the power structure within the hotel, including, the proportions of the front office staff as presented by the management of the hotel determines the behaviour of the front office personnel. Hamborstad \& Perry (2011) upheld this view as they reported that it is not the behaviour of the frontline employees in the hotel industry that determined the quality of service delivery to customers, but the structure of the hotel for which the staff are working. Abu Kassim et al (2012) posits that if there was to be any progress on offering of quality service that could translate to customer satisfaction, it would come about because the hotel organisation changed, and not necessarily the front office staff. The Spreitzer Psychological Empowerment theory on the other hand explains that employee orientation toward work characteristics rely on four determinants such as competence, impact, meaning and self-determination (Spreitzer, 1995). These are the internal stimulators that allow employees to feel or perceive they have the ability to get things done. This perception results in work effectiveness and job satisfaction (Spreitzer, 1995). As it applied to the current study, individual orientation of the hotel front office staff towards their work is determined by four factors such as competence, impact, meaning and self-determination. These four factors serve as internal stimulators that allow hotel front office staff to feel or perceive they have the ability to get things done. This perception results in quality service delivery that translated to customer's satisfaction.

\section{Lodging Quality Index Model (LQI)}

Due to the multi-dimensional nature of service quality, and the lack of consensus on how to measure service quality in the hotel industry, including, the nature of hotel services led to the development of Lodging Quality Index (LQI).LQI was developed to overcome some problem related to SERVQUAL model in accessing service quality in the hotel industry. Unlike SERVQUAL which can be used in all the service industry, LQI model were built and used only for hotel or hospitality industry. The (LQI) model was developed based on SERVQUAL (Parasuraman, et al., 1988). From the main structure and eight-step procedure of Churchill \&Supernant (1982) the lodging quality index scale was developed. The model explains service quality in hotel industry as consisting of 5 dimensions and 26 items. The five dimensions are tangible, reliability (includes original reliability and credibility dimensions), responsiveness, confidence (includes original competence, courtesy, security and access dimensions) and communication (includes original communication and understanding dimensions). The model is considered to be different from SERVQUAL model because it was developed specifically to measure service quality in the hotel industry, thus, adopted in the present study. 


\section{Expectancy-Disconfirmation Theory of Customer Satisfaction}

The expectancy disconfirmation theory is popularly used to explaining how consumers form satisfaction judgments by evaluating actual product / service. The theory broadly classified the process of satisfaction under three groups: Dissatisfaction, Satisfaction, and Extreme Satisfaction. The theory argued that the satisfaction process is the comparison of what was expected with the product or services performed (Adee, 2004; Vavra, 1997). This process has traditionally been described as the 'confirmation / disconfirmation' process (Vavra, 1997). First, customers would form expectations prior to purchasing a product or service. Second, consumption of or experience with the product or service produces a level of perceived quality that is influenced by expectations (Oliver, 1980). If the perceived performance is less than the customer's expectation, then customer is dissatisfied. Also, if the perceived performance is exactly equal to the expectation of the customer, customers are satisfied. Customers are said to be extremely satisfied when the perceived performance exceeded the customer's expectation. As it applied to the present study, the theory posits that customers would form expectations prior to arrival at the hotel. Thereafter, the consumption of or experience of the customers with the product or service rendered by the front office staff produces a level of perceived quality that is influenced by expectations (Oliver,1980). If the perceived performance is less than customer's expectation then customer is dissatisfied (Ivanka, Suzana \& Sanja, 2003). Also, if the perceived performance is exactly equal to the expectation, customers are satisfied. Customers are said to be extremely satisfied when the perceived performance exceeded the customer's expectation. In view of the applicability of this theory to the present study, the researcher adopted this two dimensional theory of customer's satisfaction in the present study.

\section{Empirical Review}

\section{Employees Empowerment and Service Quality}

Examining the definition of service quality, Lewis and Booms (1983) were perhaps the first to define the concept as a measure of how well the service level delivered matches the customer's expectations. Thereafter, there seems to be a broad consensus that service quality is an attitude of overall judgement about service superiority, although the exact nature of this attitude is still hazy. Some suggest that it stems from a comparison of performance perceptions with expectations (Parasuraman, Zeithaml, \& Berry, 1988), while others argue that it is derived from a comparison of performance with ideal standards (Teas, 1993) or from perceptions of performance alone (Cronin \& Taylor, 1992). As it applied to the hotel industry especially among the front office staff, delivering quality service is considered an essential strategy for success and survival in today's competitive hotel business (Dawkins \& Reichheld, 1990). The special feature of a service in the hotel industry is the contact and interaction between the employees (front office staff), and the customers (Tsaur et al., 2004). The quality of the service encounter plays an important role for the operation practice of the hotel front office. Besides the physical facility, customers' needs include the various service provided by the front office staff. Under keen competition in the hotel industry, how the front office staff offer the best service to customers has become the most important issue for hotel administrators. Due to the intangibility of services and the heterogeneous characteristics of hotels, including, the fact that hotel managers cannot control the service delivery process too rigidly. Thus, employees and more so the front office staff needs to retain adequate flexibility to satisfy customers within their discretion. In view of this, hotel managers have designed their own systematic standards of procedure for employees. From the viewpoint of managerial practice, those hotels which emphasize individual service, have adopted employee empowerment as a principal credo, so that the front office staff can identify customers' needs promptly and take the initiative to satisfy them. This implies that empowerment of the hotel front office staff make important contribution to service quality. Hence, when customer-contact employees are given a higher level of employee empowerment, customers are likely to have higher perceptions of service quality. Based on the above, the present study proposed that positive and significant relationship exists between employee's empowerment and service quality.

\section{Service Quality and Customer's Satisfaction}

Front office services in the hotel industry are variable because it requires customer involvement. Customers' needs are variable and therefore need a degree of employee's personal contact with the customer. Employees who are not allowed to take decisions as it affect their jobs in this service industry are unlikely able to deliver quality service. Dubrovski, (2001) observed that, the levels of service delivered by the hotel front office staff may also be affected if they are not in a positive mood to do their job. These conditions may have some impact on the value of quality that they deliver which may well have some influence on the customer's satisfaction or dissatisfaction (Khan, Ghouri, Siddiqui, Shaikh, \& Alam, 2010). The above information implies that empowerment of the front office employee is central to quality service delivery.

Empowerment improves productivity of the employees, thus, Robbins (2001) asserted that when people who actually do the work are allowed to make their own job related decisions, and both the speed and quality of those decisions often improve, thus, quality service. Furthermore, they noted that, every interaction 
the front office employee has with a customer represents an opportunity to build that customers emotional connection or to diminish it. Sparks, Bradley \& Callan (1997) reported that the hotel front office employees who are fully empowered and offer quality service to customers in attentive manner could evoke more customer satisfaction. Most hotel front office employees today are willing to accept responsibilities because they are far better educated and trained (Robbins, 2001). Ketchum \& Trist (1992) observed that empowering terms should be a central concept for hotel front office managers who wish to improve service quality. Aziri (2011) pointed out that if employees could perform with responsiveness and enthusiasm, then customers would be more satisfied in the process of service delivery.

Customer satisfaction therefore is defined as customer perception regarding a particular product / service according to his / her already set expectations (Schiffman \& Kanuk, 2005). Andreassen (2000) argued that quality in services is an essential part of customer satisfaction. He suggested that service providers should provide best quality services to their customers to ensure their satisfaction. The above information implies that service quality is commonly noted as a critical prerequisite for establishing and sustaining satisfying relationship with valued customers. It is pertinent to state that the association between service quality and customer satisfaction has emerged as a topic of significant and strategic concern (Cronin \& Taylor, 1992).

In general, perceived service quality is an antecedent to customer satisfaction in hotel industry (Spreng \& Mckoy, 1996). Thus, a proper understanding of the antecedents and determinants of customer satisfaction can be seen as to have an extraordinarily high monetary value for service organization such as hotel business in a competitive environment (Lassar, Manolis \& Winsor, 2000). Bigne, Moliner \& Sanchez (2003) found that the overall service quality have a significant relationship with satisfaction. Ham \& Hayduk (2003) have confirmed that there is a positive correlation between perception of service quality and customer satisfaction based on the relationship between each of the dimension of service quality. In view of the above the researcher assumes that a positive and significant correlation exists between service quality and customer satisfaction.

\section{Employee's Empowerment, and Customer's Satisfaction}

Sparks, et al., (1997) explore the effects of employee empowerment (full, limited, and none) on customers' satisfaction. Results revealed that fully empowered employees produce more customer satisfaction, but only when the service provider used an accommodating style of communication. Hocutt \& Stone (1998) investigated the effects of frontline employee empowerment in a service recovery situation. The results revealed that if employees were properly trained and given autonomy to make decisions, then service recovery efforts would be maximized, thus leading to higher consumer satisfaction. Zeglat, et al. (2008) analysed the effect of employee empowerment on customer satisfaction and concluded a positive relationship between the two variables. The question now is what is customer satisfaction?

Customer satisfaction therefore is defined as customer perception regarding a particular product / service according to his / her already set expectations (Schiffman \& Kanuk, 2005). When would customers feel that they are being offered products / service according to their expectations? That depends a lot on the efficiency levels of the service providers or on the people who are involved in the production process. How would efficiency level go up? This is possible through autonomy, responsibility, innovation and information (Yang \& Choi, 2009), thus, the concept of empowerment. Empowered employees are more motivated as compared to those who just follow the given lines (Naeem \& Saif, 2010). Employee empowerment creates sense of belongingness and ownership towards the parent organization, hence, made them feel more confident and try to give their best to their employers; as a result, service quality improves (Naeem \& Saif, 2010). The authors further opined that improved product or service quality generally results into higher level of customer satisfaction. Study conducted by Yang \& Choi (2009) concluded that employee empowerment can contribute a lot towards business growth and development. Business growth is largely dependent upon customer satisfaction and customer satisfaction is one of the end products of employee empowerment.

It had been established from previous literature that there is a positive correlation between employee's empowerment and customer's satisfaction (Timothy \& Abubakar, 2013; Ogutu \& Oloko, 2012; Odindo \& Delvin, 2010; Sparks, et al., 1997). It was also established that employee's empowerment did not ordinarily translate to customer satisfaction without offering of quality services. This implies that employee's empowerment that translates to quality service could lead to customer's satisfaction hence; service quality could have a mediating effect on the relationship between employee's empowerment, and customer's satisfaction. In view of this, the fact that limited study had examined the mediating effect of service quality on the relationship between employee's empowerment, and customer's satisfaction in the context of employees of the front office in hotel industry in Benin City, this article therefore aim to fill this gap. In attempt to achieve this objective, the researchers proposed that service quality have a positive mediating effect on the relationship between employee's empowerment and customer's satisfaction as shown in Figure 1. 


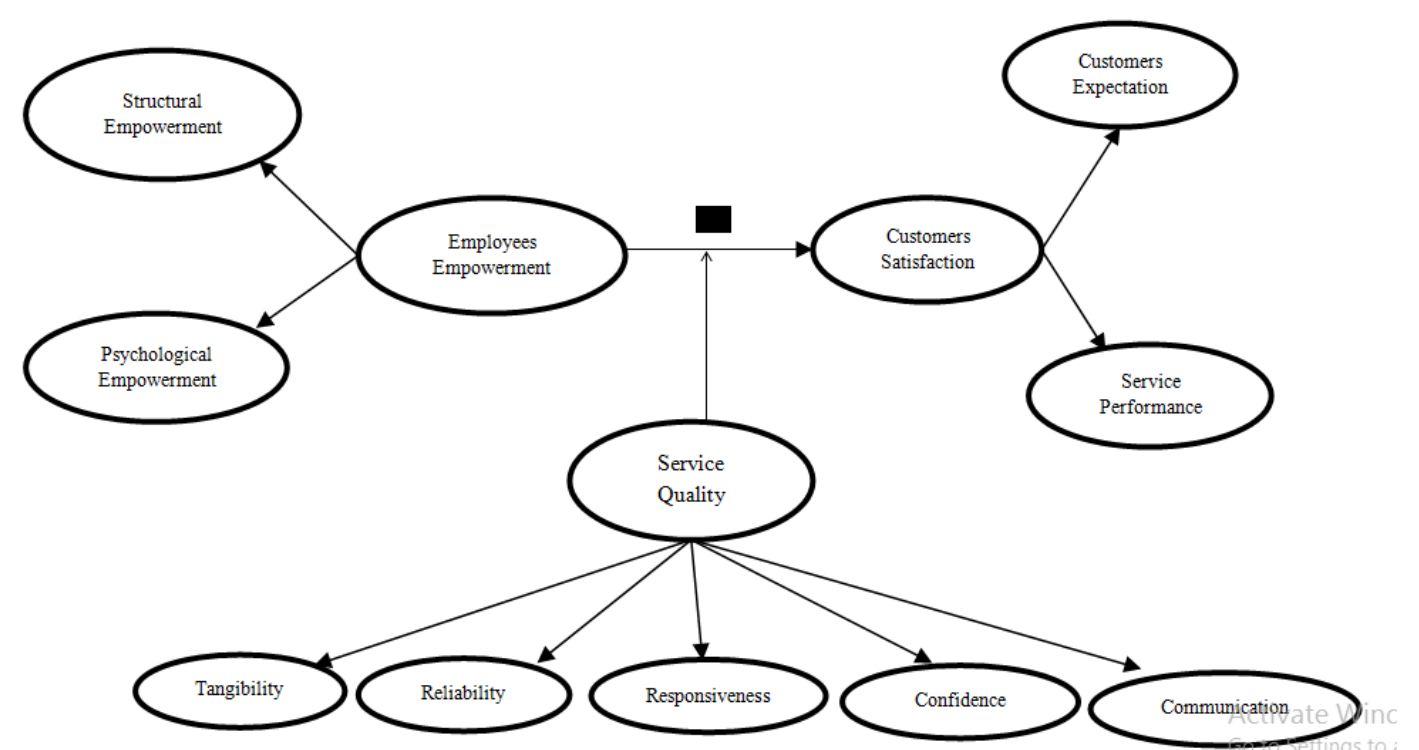

Figure 1: Mediating Effect of Service Quality on the Relationship between Employee's Empowerment and Customer's satisfaction (MSQECS).

\section{Research Methodology}

Quantitative research design is adopted in this study. The research population comprised of 20 registered five star hotels in Benin City Nigeria. The sampling units used for the research work include 10 out of the 20 registered five star hotels selected through simple random sampling. Since it is practically impossible for the researcher to sample the whole staff in each of the 10 selected hotels, hence, the researcher determines the proportion of the sample unit that constituted the sample using Yaro Yamane formula. To determine the sample size of the 10 selected hotels vis-à-vis the population of the front office staff, the present study conceded to the method of proportional allocation suggested in Kothari (1990). The concept of propositional allocation suggested that the sizes of samples from different strata are kept propositional to the sizes of the strata. Before applying the Yaro Yamane formula as suggested in Nwanna (1992), the researcher contacted the management of the 10 selected hotels to obtain the total number of the front office staff on their employment thus; the population $(\mathrm{N})$ size of 151 was obtained as shown in Appendix1. The sample size $\mathrm{n}$ of front office staff per each of the 10 selected hotels (i.e. $\mathrm{n}_{1 \cdots .10}$ ) to be drawn from the population $(\mathrm{N})$ of 151 was determined per each of the hotels as shown in Appendix 2. The results shows that the sample size of the hotel front office staff that will participate in the filling of the part $1 \& 4$ of the questionnaire is 106 staffs (Appendix 2 refered), while 106 customers participated in the filling of the part $2 \& 3$ of the questionnaire. Since it is practically impossible to access the nominal register of both the front office staff from the 10 selected hotels, including the customers, hence, the researcher opted for non-probability sampling with convenience sampling technique. The researchers personally visited each of the 10 targeted hotels in Benin City and, thus, administered the structured questionnaires in the 10 selected hotels until the sample size of 106 for each of the staff and customers is met.

Prior to administering the questionnaires, a pilot test was conducted to determine the extent at which the items in the instrument measure each of the constructs. The first round measurement instrument was pretested on about 50 front office staff, including, customers from the target population. The three variables in the questionnaires were tested for its reliability using SPSS version 22. The reliability test for each of the three constructs in the instrument was examined for its Cronbach's Alpha. The outcome of the analysis shows that each of the three constructs in the instrument has a Cronbach's Alpha reading $>0.7$. This finding is in conformity with the suggestion in Hair et al. (2006) and Nunnally (1978) that a Cronbach's Alpha reading above 0.7 are considered satisfactory, hence, showing that items in the instrument measure their corresponding constructs as shown in Appendix 3. To validate the instrument, expert judgement was used; hence copies of the scale were made available to experts for validation. Pilot test was also conducted to determine the validity of the scale. Hair et al. (2010) suggested the usage of factor loading, hence the composite reliability, including, the item loading should be $>.6$. The result of this analysis shows that all the items in the instrument are valid as presented in Appendix 4a-c. Multiple regressions allow the exploration of the interrelationship among a set of variables (Pallant, 2010) were adopted for the analysis of data collected. Before proceeding with the analysis of objectives in the present study, the researcher carefully screen the data. The initial data analysis in terms of missing values, influential outliers, normality, and multicollinearity were conducted using statistical package for social science (SPSS) software version 22. 


\section{Data Analysis, Findings and Discussion}

The psychometric properties of dimensions of structural and psychological empowerment among front office staff in Hotel Industry in Benin City were assessed based on Cronbach's Alpha. The results of the Cronbach's Alpha value of all individual items for each of the two dimensions of employee's empowerment range between .775 and .957 . The conclusion that could be reached based on this finding is that all items measure their underlying dimensions consistently (Coakes et al., 2009). The composite reliability for each of the two aggregate dimensions of employee's empowerment ranges between $0.811-0.966$. This suggests that the composite reliability score of the two dimensions: - Structural empowerment, $(\alpha=0.811)$, and Psychological empowerment, $(\alpha=0.966)$ shows that they are all statistically reliable. This implies that items for the two measures of employee's empowerment in the context of hotels in Benin City are internally consistent (Barrett, 2007). Furthermore, the results of the reliability analysis of the service quality show that the reliability coefficients value of all the individual items ranges between 0.803 and 0.952 . This suggests that all the items measure their underlying dimensions consistently (Coakes et al., 2009). The composite reliability score for each of the five aggregate dimensions of service quality ranges from .827and 0.948. Tangibility, $(\alpha=.827)$, Reliability, $(\alpha=.925)$, Responsiveness, $(\alpha=.948)$, Confidence, $(\alpha=.947)$, and Communication, $(\alpha=0.942)$. This justifies that all the items for the five measures of service quality are internally consistent. The reliability of customer's satisfaction was assessed using Cronbach's alpha. The reliability coefficients value of all the individual items ranges between 0.803 and 0.952 . This suggests that all the items measure their underlying dimensions consistently (Coakes et al., 2009).The composite reliability score for customer satisfaction in hotel industry in Benin City is 0.879. This justifies that all the items for the variable (Customer satisfaction) in hotel industry in Benin City, Edo State are internally consistent.

\section{Analysis of the Mediating Effect of Service Quality on the Relationship between Employees Empowerment, and Customer Satisfaction}

To achieve this objective, hierarchical multiple regressions were used to assess the ability of control of employee's empowerment to predict levels of customer's satisfaction, after controlling for the influence of service quality. This enables the researcher to establish the existence of mediation, and the type of the mediation. The mediating effect otherwise known as intervening effect, describe the effects of a mediating variable in the relationship between an independent variable and its corresponding dependent variable in a model (Zainudin, 2012). In testing for mediation, a number of approaches were suggested in literature (Zainudin, 2012; Baron and Kenny, 1986). However, due to ease of computation and interpretation, mediation test via comparison of the direct model (i.e. Model 1), and mediation model (i.e. Model 2) as suggested in Baron and Kenny (1986) was adopted in the present study. The authors summarised mediating test approach as shown in Table 1 and 2 .

Table 1: Mediating Test via Comparison of the Direct Model (Model 1), and Mediation Model (Model 2)

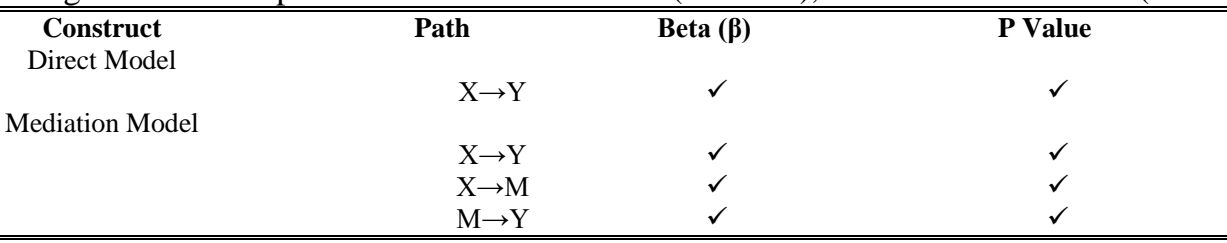

Table 2: Rule of Thumb for Mediating Test via Comparison of the Direct Model (Model 1), and Mediation Model (Model 2)

\begin{tabular}{|c|c|c|c|c|c|}
\hline \multirow{2}{*}{$\begin{array}{l}\text { Decision } \\
\text { Rule }\end{array}$} & \multirow{2}{*}{$\begin{array}{c}\text { Direct Model } \\
\mathrm{X} \rightarrow \mathrm{Y}\end{array}$} & \multicolumn{4}{|c|}{ "Mediation Model } \\
\hline & & & $\mathrm{X} \rightarrow \mathrm{Y}$ & $\mathrm{X} \rightarrow \mathrm{M}$ & $\mathrm{M} \rightarrow \mathrm{Y}$ \\
\hline & $\mathrm{P}$ & Beta $(\beta)$ & $\mathrm{P}$ & $\mathrm{P}$ & $\mathrm{P}$ \\
\hline Full Mediation & S & $\downarrow$ & NS & S & S \\
\hline Partial Mediation & S & $\downarrow$ & $\mathrm{S}$ & S & S \\
\hline No Mediation & & & & NS & NS \\
\hline Indirect Effect & NS & & NS & $\mathrm{S}$ & $\mathrm{S}$ \\
\hline
\end{tabular}

Note: $\downarrow=$ Reduced; P=Significant. Value; NS=Not Significant; S=Significant.

Baron and Kenny (1986)

As it applied to the present study, the direct effect of empowerment on customer satisfaction, including the mediating effect of service quality on the relationship between employee's empowerment on customer satisfaction in hotel industry in Benin City is assessed based on the rule of thumb of mediating test via comparison of the direct and mediation model as shown in Table 1 and 2. Therefore, the rule applies that: 
1. A full mediation exist if: i. the $p$ value of the relationship between employee's empowerment and customer satisfaction in the direct model (model 1) is significant, ii. The regression coefficient of employee's empowerment and customer satisfaction in the mediation model is reduced and the $\mathrm{p}$ value not significant, iii. The $\mathrm{p}$ value of the relationship between employee's empowerment and service quality, including, the relationship between service quality and customer satisfaction in the mediation model (Model 2) are significant. 2. A partial mediation is said to exist if: i. the $p$ value of the relationship between employee's empowerment and customer satisfaction in the direct model is significant, ii. The regression coefficient of employee's empowerment on customer satisfaction in the mediation model is reduced and the $\mathrm{p}$ value is significant, iii. The $p$ value of the relationship between employee's empowerment and service quality, including the $p$ value of the relationship between service quality and customer satisfaction in the mediation model are both significant.

3. No mediation exists if: the $p$ value of the relationship between employee's empowerment and service quality, and the $\mathrm{p}$ value of the relationship between service qualities on customer satisfaction in the mediation model are not significant.

4. Indirect mediating effect exists if: i. the p value of employee's empowerment and customer satisfaction path in the direct model is not significant, ii. The $\mathrm{p}$ value of both the employee's empowerment and service quality path, including the service quality on customer satisfaction path in the mediation model are significant.

The result of the hypothesis as proposed and tested is shown in Table 3 and 4.

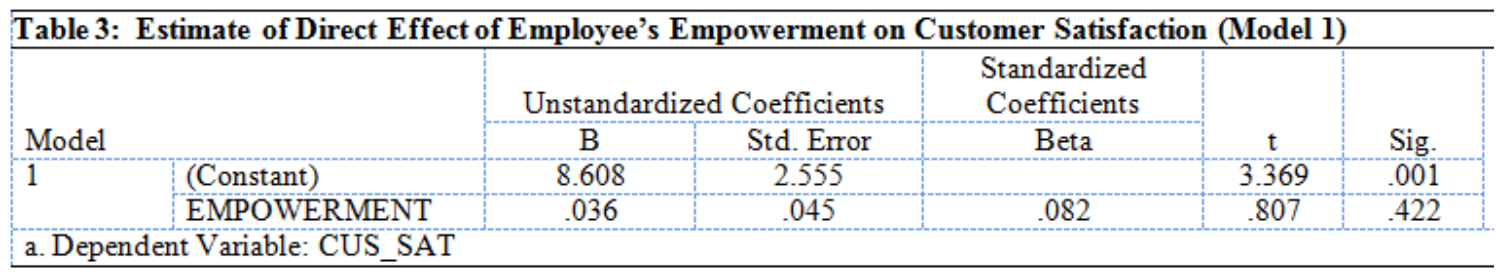

In the direct model (Model 1) as shown in Table 3, the results revealed that the regression coefficient of employee's empowerment on customer satisfaction is 0.082 . The level of significant for regression weight reveals that the probability of getting a critical ratio as large as 8.608 in absolute value is 0.422 . This implies that the direct effect of employee's empowerment on customer satisfaction is not significant. Furthermore, the indirect model (model 2), assessed the direct effect of employee's empowerment on customer's satisfaction in hotel industry in Benin City for its regression coefficients as shown in Table 4.

\begin{tabular}{|c|c|c|c|c|c|c|}
\hline \multirow{2}{*}{\multicolumn{2}{|c|}{ Model }} & \multicolumn{2}{|c|}{ Unstandardized Coefficients } & \multirow{2}{*}{$\begin{array}{c}\text { Standardized } \\
\text { Coefficients } \\
\text { Beta }\end{array}$} & \multirow[b]{2}{*}{$\mathrm{t}$} & \multirow[b]{2}{*}{ Sig } \\
\hline & & $\mathrm{B}$ & Std. Error & & & \\
\hline \multirow[t]{2}{*}{1} & (Constant) & 8.732 & 6.45 & & 4.369 & .001 \\
\hline & EMPOWERMENT & .066 & .055 & .0532 & .507 & .355 \\
\hline \multirow[t]{3}{*}{2} & (Constant) & 12.142 & 3.175 & & 3.825 & .000 \\
\hline & EMPOWERMENT & .053 & .045 & .120 & 1.166 & .042 \\
\hline & SER QUALITY & -.048 & .026 & -.189 & -1.836 & .027 \\
\hline
\end{tabular}

The output revealed that the beta coefficient of employee's empowerment on customer satisfaction reduces to 0.532 from 0.082 compared to the value of the beta coefficient in the direct model (See Table 3 ). The level of significant for regression weight of employee's empowerment on customer satisfaction as shown in Table 4reveals that the probability of getting a critical ratio as large as 8.732 in absolute value is 0.355 , hence, not significant. Furthermore, the level of significant for regression weight of employee's empowerment on service quality shows that the probability of getting a critical ratio as large as 12.142 in absolute value is 0.042 , thus, supported the path. In addition, the level of significant for regression weight of service quality on customer satisfaction shows that the probability of getting a critical ratio as large as 12.142 in absolute value is 0.027 , thus, supported the path. This implies that indirect mediation exists between employee's empowerment and customer satisfaction through service quality.

\section{Discussion of Findings}

The result of the direct effect of employee's empowerment (i.e. Independent variable (IV) on customer satisfaction (i.e. Dependent variable (DV) is not significant. The results of the indirect effect of employee's empowerment on customer satisfaction on the mediation model revealed that the value of the beta coefficient reduces, and the regression weight not significant. This implies that the regression weight for employee's empowerment in the prediction of customer satisfaction in hotel industry in Benin City is not significantly 
different from zero at the 0.001 level of (two tail test). Hence, employee's empowerment among the front office staff of hotels in Benin City did not have a significant and direct effect on customer satisfaction. Furthermore, the results of level of significant for regression weight of employee's empowerment on service quality in the mediating model (Model 2) shows that the probability of getting a critical ratio as large as 12.142 in absolute value is < than 0.005 thus, significant. This implies that the regression weight for employee's empowerment in the prediction of service quality in hotels in Benin City is significantly different from zero at the 0.042 level of (two tail test). Thus, concluded that employee's empowerment among the front office staff in hotels in Benin City, has a significant and direct effect on service quality, hence, supported hypothesis 6 . Finally, the level of significant for regression weight of service quality on customer satisfaction revealed that the probability of getting a critical ratio as large as 12.142 in absolute value is $<0.005$, hence, supported the path. This implies that the regression weight for service quality in the prediction of customer satisfaction in hotel industry in Benin City is significantly different from zero at the 0.027 level of (two tail test). The result suggests that the service quality among the front office staff in hotels in Benin City has a significant and direct effect on customer satisfaction. The conclusion that could be reached based on the above findings is that the service quality has indirect mediating effect on the relationship between employee's empowerment and customer satisfaction in the hotel industry in Benin City.

\section{Conclusions from Findings}

The present study were conducted on the basis of the combination of Kanter's structural and, Spreitzer's psychological empowerment theories, Lodging Quality Index (LQI) theory of service quality, and expectancy-disconfirmation theory of customer satisfaction. This is because no single theory have been reported as being able to explain the relationship between employee's empowerment, service quality, and customer's satisfaction in the context of hotels in Benin City. Congruently, in accordance with the employee's empowerment, service quality, and customer's satisfaction framework (MSQECS) used for this study, Hypothesis predictions were developed in consonance with previous literature that explored the mediating effect of service quality on the relationship between employee's empowerment, and customer's satisfaction in the context of hotels in Benin City. Fortunately, answers to this objective have been found; while the proposed hypotheses were investigated and found to be supported. It is therefore critical to state that the service qualities that emanates from empowered contact staff especially the front office staff could be annexed towards successful packaging of hotel industry in Nigeria, thus, enhancing service quality that make Nigerian hotel a tourist delight. Similarly, when hotel managers empowered their contact staff, there is tendency for better performance of the industry and as well improvement in the nations' GDP. It was concluded that empowered front line staff triggers quality service delivery, hence, managers of hotel industry should put in place management practice that will stimulate impact, confidence, competence, and self-determination. This will ensure that quality service that could translate to customer satisfaction is delivered.

\section{References}

[1] Ahmed, H., \& Rafiq, H . (2003). Marketing Principles and Perspectives (3rd ed.) . New York: Mc Graw Hill.

[2] Andreassen, T. W. (2000). Antecedents to Satisfaction with Service Recovery. European Jounrnal of Marketing, 34 , (1), $156-175$.

[3] Aziri, B. (2011). Job Satisfaction: A Literature Review. Management Research and Practice , 3, (4), 77.

[4] Baron, R. M., and Kenny, D. A. (1986). The Moderator-Mediator Variable Distinction in Social Psychology Research: Conceptual, Strategic, and Statistical Considerations. Journal of Personality and Social Psychology, 51, (6), 1173.

[5] Bello, Y. O. (2012). Hospitality Economics (A Simplified Approach) in the Nigerian Hospitality Industry (2nd Ed.). Ondo: Grace Excellent Publishers.

[6] Bello, Y. O., and Bello, M. B. (2015). Lodging Service Management and Administration, Theory and Practice. Benin: Diamond Publishing House.

[7] Bigne, E., Moliner, M. A., \& Sanchez, J. (2003). Perceived Quality and Satisfaction in Multi Service Organizations: The Case of Spanish Public Services. The Journal of Services Marketing, 17, (4), 420-442.

[8] Coakes, S. J., Steed, L., and Ong, C. (2009). Analysis Without Anguish: SPSS Version 16.0 for Windows. Australia: John Wiley and Sons Ltd.

[9] Cronin, J. J., \& Taylor, S. A. (1992). Measuring Service Quality: Reexamination and Extension. Journal of Marketing, 56, (1), 5568.

[10] Dawkins, P., \& Reichheld, F. (1990). Customer Rtention as a Cmpetitive Wapon. Directors and Board, 14, (1), 42-47.

[11] Dubrovski, D. (2001). The Role of Customer Satisfaction in Achieving Business Excellence. Journal of Total Quality Management, $12,(7 / 8), 920-925$.

[12] Gronroos., C. (2001). Service Management and Marketing: A Customer Relationship Management . Great Britain : Pearson Education Limited.

[13] Hair, J. F., Black, W. C, Babin J. Barry, and Anderson, R. E. (2010). Multivariate Data Analysis (7ed). New Jersey: Prentice-Hall.

[14] Hair, J. F., Black, W. C., Babin, B. J., Anderson, R. E., and Tatham, R. L. (2006). Multivariate Data Analysis (6th Ed.) . Upper Saddle River, NJ: Pearson Prentice Hall.

[15] Ham, L., \& Hayduk, S. (2003). Gaining Competitive Advantages in Higher Education: Analyzing the Gap between Expectations and Perceptions of Service Quality. International Journal of Value-Based Management, 16, (3), 223-242.

[16] Hocutt, M., \& Stone, T. (1998). The Impact of Employee Empowerment on the Quality of a Service Recovery Effort. Journal of Quality Management, 3, (1), 117-132. 
[17] Igbojekwe, P. (2002). In C. I. Okoli, Food Service Operations in the Hospitality Industry. Owerri: Unique Books, WEBS Media Commuication.

[18] Isimoya, A. O., \& Bakarey, B. E. (2013). Employees' Empowerment and Customers' Satisfaction in Insurance Industry in Nigeria. Australian Journal of Business and Management Research, 3, (5), 1-11.

[19] Ketchum, L. D., \& Trist, E . (1992). All Teams are not Created Equal. How Employee Empowerment Really Works. Newbury Park, and CA 106: Sage.

[20] Khan, N. R., Ghouri, A. M., Siddiqui, U. A., Shaikh, A., \& Alam, I. (2010). Determinant Analysis of Customer Switching Behavior in Private Banking Sector of Pakistan. Interdisciplinary Journal of Contemporary Research in Business, 2, (7), 96-110.

[21] Kothari, C. .. (1990 ). New Age Research Methodology; Methods and Techniques (2nd Ed). New Delhi: New Age International (P) Limited.

[22] Lassar, W. M., Manolis, C., \& Winsor, R. D. (2000). Service Quality Perspectives and Satisfaction in Private Banking. Journal of Service Marketing, , 14, (3), 244-271.

[23] Lewis, R.C., \& Booms, B. H. (1983). The Marketing Aspects of Service Quality. In L. Berry, Shostack, G, \& Upah, G, Emerging Perspectives on Services Marketing (pp. 99-107). Chicago: American Marketing.

[24] Naeem, H., \& Saif, M. I. (2010). Employees Empowerment and Customers' Satisfaction in Pakistan. African Formal of Business Management, 4, (10), 1-10.

[25] Nunnally, J. C. (1978). Psychometric Theory (2nd ed.) . New York : McGraw Hill.

[26] Nwanna, O. C. (1992). Introduction to Educational Research. Ibadan: Heinemann Educational Books Nigeria Plc.

[27] Odindo, C. \& Delvin, J. (2010). Customer Satisfaction, Loyalty and Retention in Financial services. Retrieved from Financial Service Research Forum: www.nothingham.ac.uk/business/forum/documents, on 11th November

[28] Ogutu, M., \& Oloko, M. (2012). nfluence of Power Distance on Employee Empowerment and MNC Performance: A Study of Multinational Corporations in Kenya. Educational Research Journal , 2, (2), 47-61.

[29] Pallant, J. (2010). SPSS Survival Manual: A Step by Step Guide to Data Analysis Using SPSS. McGraw-Hill International.

[30] Palmer, A. (2001). Principles of Services Marketing (3rd ed.). Berkshire: McGraw-Hill.

[31] Parasuraman, A. Z., Valarie, A., and Berry, L. L. (1988). A Conceptual Model of Service Quality and Its Implications for Future Research. Journal of Marketing, 49, (4), 41-50.

[32] Robbins, S. P. (2001). Organizational Behaviour;Concepts Controversies and Applications. USA: Prentice Hall International Inc.

[33] Schiffman, L. G., \& Kanuk, L. L . (2005). Consumer Behavior, Introduction: The Impact of Digital Revolution on Consumer Behavior. New York: McGraw Hill.

[34] Sparks, B., Bradley, G., Callan, V . (1997). The Impact of Staff Empowerment and Communication Style on Customer Evaluations: The Special Case of Service Failure. Psychology and Marketing, 14, (3), 475-493.

[35] Spreng, R. A., \& Mackoy, R. D. (1996). An Empirical Examination of a Model of Perceived Service Quality and Satisfaction. Journal of Retailing, 72, (2), 52-64.

[36] Teas, R. K. (1993). Consumer Expectations and the Measurement of Perceived Service Quality. Journal of Professional Services Marketing, 8, (2), 33-54.

[37] Timothy, A. L., \& Abubakar, H. (2013). Impact of Employee Empowerment on Service Quality- An Emperical Analysis of the Nigerian Banking Industry. British Journal of Marketing Studies, 1, (4), 32-40.

[38] Tsaur, S., Chang, H., \& Wu, C. (2004). Promoting Service Quality with Employee Empowerment in Tourist Hotels:The Role of Service Behavior. Asia Pacific Management Review, 9, (3), 435-461.

[39] Yang, S. B., \& Choi, S. O. (2009). Employee Empowerment and Team Performance: Autonomy, Responsibility, Information and Creativity. Journal of Team Perform Management, 15, (5/6), 289-30.

[40] Zainudin, A. (2012). Structural Equation Modelling Using AMOS Graphic. Shah Alam: Universiti Teknologi Mara Publication Centre (UPENA).

[41] Zeglat, D., Aljaber, M., \& Alrawabdeh, W. (2014). Understanding the Impact of Employees Empowerment on Customers Satisfaction. Journal of Business Studies Quarterly, 6, (1), 1-13

Appendix 1: Summary of Observation Unit of the Front Office Staff in the Selected Hotels in Benin City

\begin{tabular}{|c|c|c|c|}
\hline Town & Name of Hotels & \multirow{3}{*}{$\begin{array}{l}\text { Evbuomwan Street, off Sapele Rd. Etete, } \\
\text { Benin City } \\
\text { No } 1 \text { Oguigo Avenue, Along Adeyan Street } \\
\text { Off Ihama Rd., GRA Benin City. } \\
\text { No } 11 \text { Nneka Street, GRA, Benin City. } \\
\text { No } 10 \text { Agbonrofo St. GRA, Benin City. } \\
\text { No } 4 \text { Sakpoba Rd. Benin City. } \\
\text { No } 2 \text { AdenomoCresent, Etete, GRA, Benin } \\
\text { City. } \\
\text { 1A Reservation Rd. GRA, Benin City. } \\
\text { No } 1 \text { Ihama Rd., by Airport Rd Junction, } \\
\text { GRA Benin City. } \\
\text { No } 22 \text { Ihama Rd., by Airport Rd Junction, } \\
\text { GRA Benin City. } \\
\text { No } 50 \text { Uziegbe St. Benin City } \\
\end{array}$} & No of Front Office Staff \\
\hline $\begin{array}{l}\text { Benin } \\
\text { City }\end{array}$ & $\begin{array}{l}\text { Best Western Homeville Hotel } \\
\text { Boston Hotel } \\
\text { Choice Gate Hotel and Suite. } \\
\text { Kenbril Hyatt Hotel. } \\
\text { Lixborr Hotel. } \\
\text { Meridan Lodge. } \\
\text { Motel Benin Plaza. } \\
\text { Prestige Hotel and Suite, } \\
\text { Royal Marble Hotel. } \\
\text { Uyi Grand Hotel and Suite. }\end{array}$ & & $\begin{array}{l}16 \\
14 \\
15 \\
15 \\
14 \\
13 \\
15 \\
16\end{array}$ \\
\hline & $\begin{array}{c}\text { Total Population of the Front Office } \\
\text { Staff }\end{array}$ & & 151 \\
\hline
\end{tabular}


Appendix 2: Sample Size Determination Using Yaro Yamane Formula

1. Sample size for Best Western Homeville

$$
\begin{gathered}
\mathrm{n}=\mathrm{x} \\
\hline 1+\mathrm{N}(\mathrm{e})^{2} \\
=\quad 18 \\
\hline 1+151(.05)^{2} \\
=13 .
\end{gathered}
$$

2. Sample size for Boston Hotel

$$
\begin{gathered}
\mathrm{n}=\quad \mathrm{x} \\
\hline 1+\mathrm{N}(\mathrm{e})^{2} \\
=\quad 15 \\
\hline 1+151(.05)^{2} \\
=10
\end{gathered}
$$

3. Sample size for Choice Gate Hotels and Suites

$$
\begin{gathered}
\mathrm{n}=\quad \mathrm{x} \\
\hline 1+\mathrm{N}(\mathrm{e})^{2} \\
=\quad 16 \\
\hline 1+151(.05)^{2} \\
=12
\end{gathered}
$$

4. Sample size for Kenbrill Hyatt Hotel

$$
\begin{gathered}
\mathrm{n}=\mathrm{x} \\
\hline 1+\mathrm{N}(\mathrm{e})^{2} \\
=\quad 14 \\
\hline 1+151(.05)^{2} \\
=10 .
\end{gathered}
$$

5. Sample size for Lixborr Hotels

$$
\begin{gathered}
\mathrm{n}=\quad \mathrm{x} \\
\hline 1+\mathrm{N}(\mathrm{e})^{2} \\
=\quad 15 \\
\hline 1+151(.05)^{2} \\
=10
\end{gathered}
$$

6. Sample size for Meridan Lodge

$$
\begin{gathered}
\mathrm{n}=\mathrm{x} \\
\hline 1+\mathrm{N}(\mathrm{e})^{2} \\
=\quad 14 \\
\hline 1+151(.05)^{2} \\
=10
\end{gathered}
$$


7. Sample size for Motel Benin Plaza

$$
\begin{array}{cc}
\mathrm{n}= & \mathrm{x} \\
\hline 1+\mathrm{N}(\mathrm{e})^{2} \\
= & 14 \\
\hline 1+151(.05)^{2} \\
=10
\end{array}
$$

8. Sample size for Prestige Hotel and Suites

$$
\begin{gathered}
\mathrm{n}=\quad \mathrm{x} \\
\hline 1+\mathrm{N}(\mathrm{e})^{2} \\
=\quad 13 \\
\hline 1+151(.05)^{2} \\
=9
\end{gathered}
$$

9. Sample size for Royal Marble Hotels

$$
\begin{gathered}
\mathrm{n}=\quad \mathrm{x} \\
\hline 1+\mathrm{N}(\mathrm{e})^{2} \\
=\quad 15 \\
\hline 1+151(.05)^{2} \\
=10
\end{gathered}
$$

10. Sample size for Uyi Grand Hotel and Suite

$$
\begin{array}{cc}
\mathrm{n}= & \mathrm{x} \\
\hline 1+\mathrm{N}(\mathrm{e}) f^{\mathrm{R}} \\
= & 16 \\
\hline 1+151(.05)^{2}
\end{array}
$$

Appendix 3: Composite Reliability of Individual Variables

\begin{tabular}{lcc}
\hline \hline Constructs & Number of Items & Cronbach's Alpha \\
\hline Structural Empowerment & 9 & .767 \\
Psychological Empowerment & 6 & .754 \\
Tangibility & 5 & .768 \\
Reliability & 4 & .775 \\
Responsiveness & 5 & .809 \\
Confidence & 5 & .718 \\
Communication & 4 & .814 \\
Satisfaction & 4 & 831 \\
\end{tabular}

Bello Yekinni Ojo Ph.D. "Mediating Effect of Service Quality on the Relationship between Employees Empowerment, and Customer Satisfaction in Hotel Industry." IOSR Journal of Business and Management (IOSR-JBM) 19.7 (2017): 77-87. 